\title{
Effects of Water-Resource Development on Yellowstone River Streamflow, 1928-2002
}

\section{Streamflow in the Yellowstone River}

Major floods in 1996 and 1997 intensified public concern about the effects of human activities on the Yellowstone River in Montana. In 1999, the Yellowstone River Conservation District Council (YRCDC), whose members are primarily representatives from the conservation districts bordering the main stem of the Yellowstone River, was formed to promote wise use and conservation of the Yellowstone River's natural resources (Yellowstone River Conservation District Council, 2014). No major dams or reservoirs are located on the main stem of the Yellowstone River making it one of the longest free-flowing rivers in the United States (fig. 1); however, many uses of the river alter streamflows. The YRCDC is working with the U.S. Army Corps of Engineers (USACE) to understand the cumulative hydrologic effects of waterresource development in the Yellowstone River Basin (fig. 1). Hydrologic effects are a critical component of the overall cumulative effects studies, which have been designed to evaluate the collective effect of a wide variety of human activities on streamflows in the river.

Since the 19th century, water from the Yellowstone River Basin has been diverted for irrigation, mining, municipalities, and others uses (PBS\&J, 2009). Streamflows have been measured by the U.S. Geological Survey (USGS) and other Federal and State agencies since the late 1800 s at sites throughout the Yellowstone River Basin (Chase, 2014). At any given time, streamflows measured by streamgages are affected by water withdrawals for irrigation, tributary reservoirs, and other water uses, as well as water added back into the river by tributary reservoir releases and irrigation return flows (Chase 2013, 2014). Irrigation and tributary reservoirs affect both

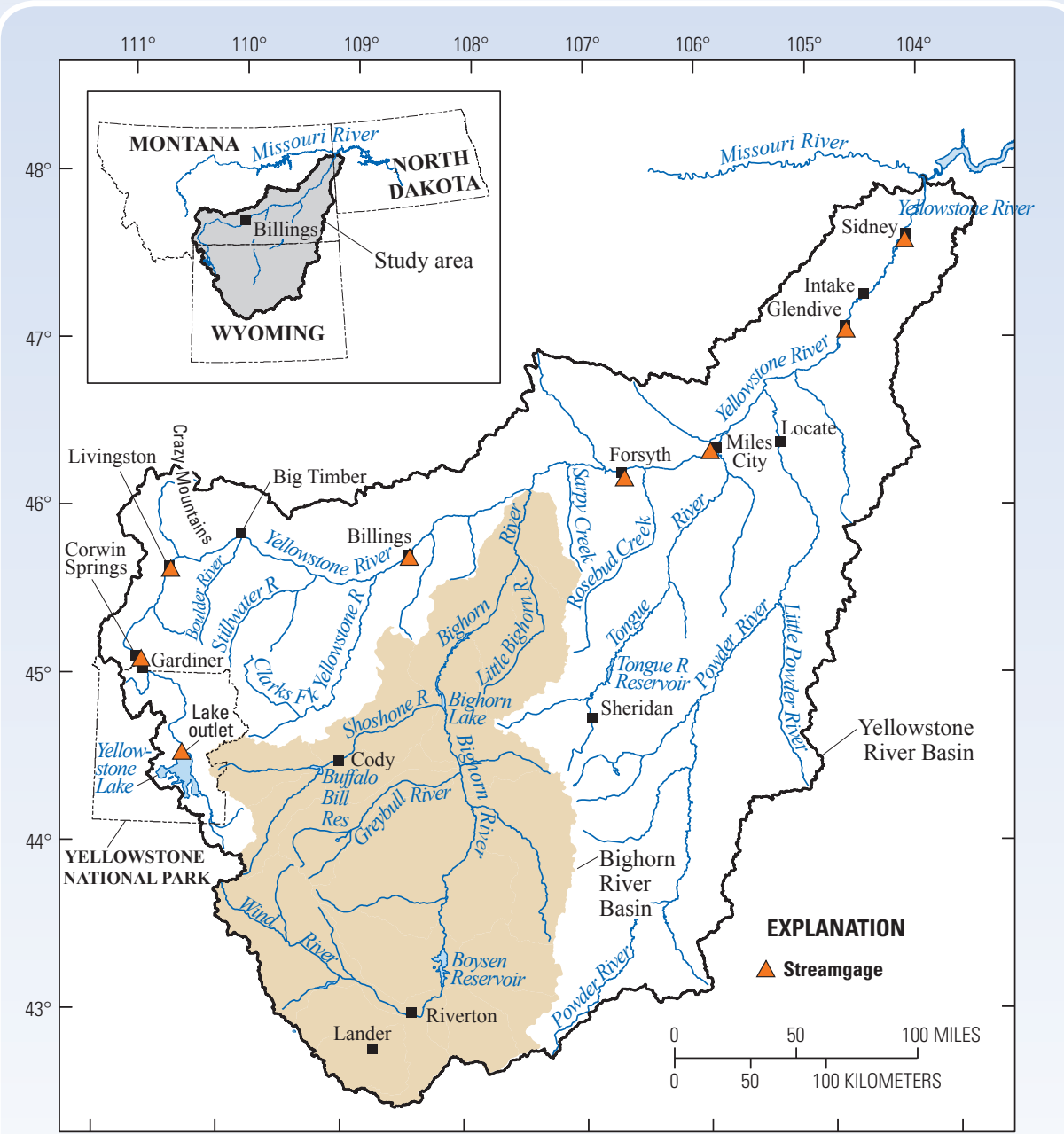

Base modified from U.S. Geological Survey Digital Line Graph (DLG), 1973, 1:2,000,000

Lambert Conformal Conic projection, standard parallels $45^{\circ} \mathrm{N}$ and $49^{\circ} \mathrm{N}$, central meridian $109^{\circ} 30^{\prime} \mathrm{W}$ North American Datum of 1983 (NAD 83)

Figure 1. The Yellowstone River Basin consists of the main stem of the Yellowstone River and four major tributaries: Bighorn River, Clarks Fork of the Yellowstone River, Powder River, and Tongue River. Eight U.S. Geological Survey streamgages were selected to analyze flows at various points in the river and are described in this fact sheet.

the timing and quantity of streamflow. In the Yellowstone River Basin, irrigation systems and tributary reservoirs generally hold (or divert) water in the spring and summer and release water to the stream in the fall and winter (U.S. Army Corps of Engineers, 2011a, 2011b). Therefore, streamflows for some months, typically in the spring and summer, are lower than they would be naturally because of irrigation diversions or the temporary holding of water in reservoirs upstream, and because of water losses due to evaporation and seepage. Conversely, in the fall 
and winter, when water is released from irrigated fields or a reservoir upstream, streamflows are higher than they would be naturally. In addition to the streamflow that typically leaves the Yellowstone River Basin when the Yellowstone River flows into the Missouri River, each year, some water is removed from the Yellowstone River Basin because of evapotranspiration from reservoirs and irrigated fields and seepage from reservoirs and irrigation canals.

\section{Calculating Streamflow Statistics Using Data from 1928 to 2002}

The USACE, YRCDC, and USGS began cooperatively studying the Yellowstone River in 2010, publishing four reports describing streamflow information for selected sites in the Yellowstone
River Basin,1928-2002 (U.S. Army Corps of Engineers, 2011a, 2011b; Chase, 2013, 2014). Detailed information about the methods used, as well as summary streamflow statistics, are available in the four reports. The purpose of this fact sheet is to highlight findings from the published reports and describe the effects of water use and structures, primarily dams, on streamflow in the Yellowstone River Basin. The definitions of technical terms used in this fact sheet are shown in the sidebar on page 3 .

Observed streamflow records from USGS streamgages (fig. 2) served as the basis for all calculations. In order to estimate the effects of water use, streamflow datasets for a daily time-step were constructed (using the observed streamflow records) to represent streamflow for two different scenarios. Datasets constucted to represent streamflow without waterresource development are defined as "unregulated flow," and the datasets representing streamflow with water-resource development are defined as "regulated flow." Streamflow statistics, such as annual mean streamflows, mean low flows, and peak streamflows, were then calculated for unregulated and regulated conditions for sites on the Yellowstone River, and on the Bighorn, Tongue, and Powder Rivers for the years 1928-2002 (U.S. Army Corps of Engineers, 2011a, 2011b; Chase, 2013, 2014). In this fact sheet, comparisons between unregulated and regulated streamflow statistics for a few selected Yellowstone River locations (fig. 1) are used to describe the effects of water-resource development on the Yellowstone River Basin.

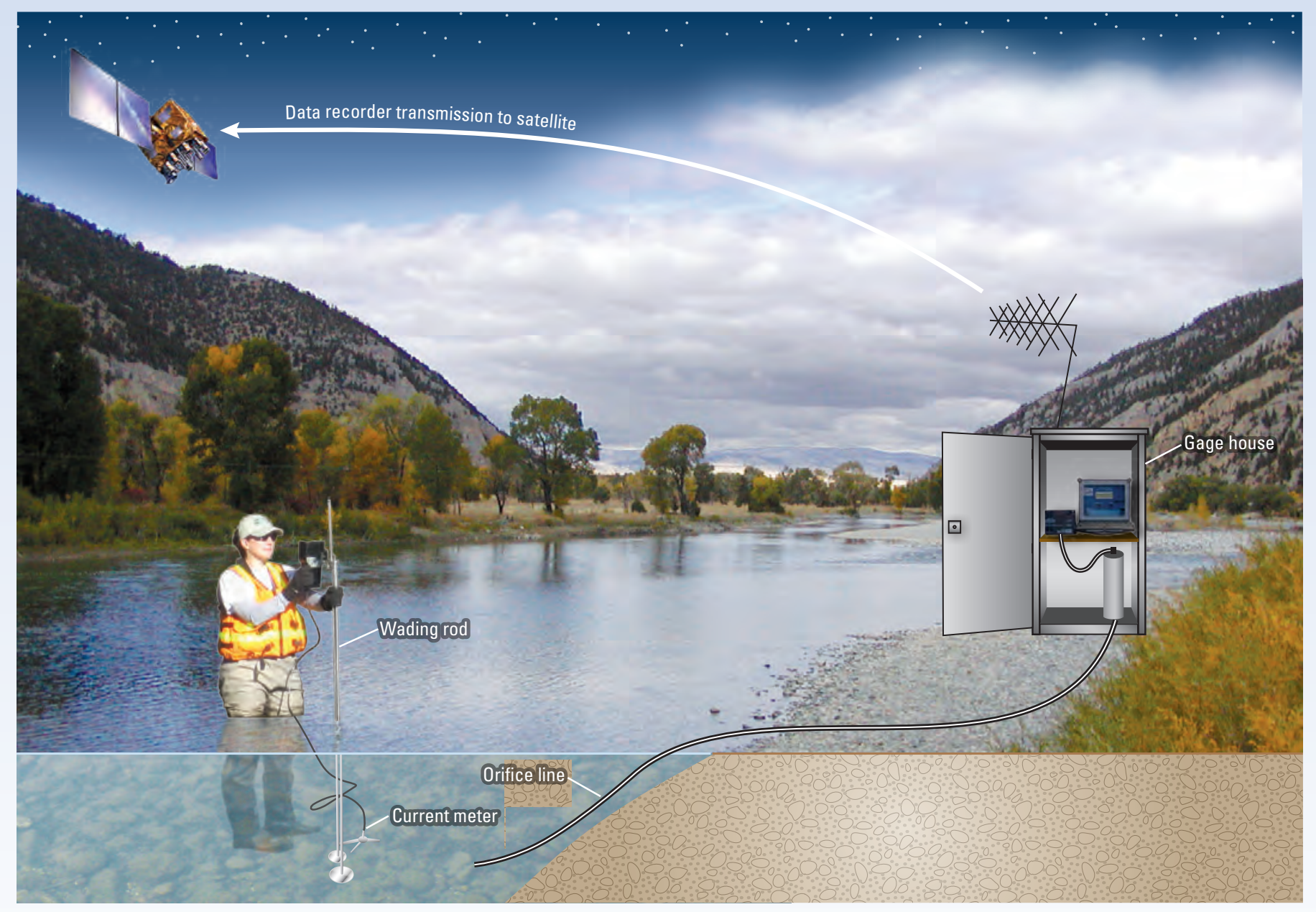

Figure 2. Stream stage is measured every 15 minutes by instrumentation at a streamgage and transmitted by satellite to U.S. Geological Survey computers; the data collected are referred to as real-time data. Periodic stream stage and streamflow measurements are made by U.S. Geological Survey hydrographers to ensure accuracy of the real-time data. Streamflow information is displayed on the web and can be accessed at http://waterdata.usgs.gov/nwis. (Details about the entire process of displaying real-time streamflow data on the web can be found in Olson and Norris, 2005). 


\section{Comparing Streamflow Changes During the Course of a Year}

Comparing unregulated and regulated hydrographs (graphs showing daily streamflows during the course of a year) can provide insight into how water-resource development in the Yellowstone River Basin affects streamflows in the Yellowstone River. Unregulated (without water-resource development) and regulated (with water-resource development) streamflows are compared for the Yellowstone River streamgages at Billings and at Forsyth for a typical water year (October 1-September 30) in 1979 (fig. 3). At both locations, the regulated hydrograph, which includes the effects of water-resource development, shows differences when compared to the unregulated hydrograph because of stream diversions during the spring and summer for irrigation, reservoir storage, and other uses.

\section{Unregulated and Regulated Low Flows along the Yellowstone River}

Low streamflows in a river are of particular concern to irrigators needing to apply sufficient water for crops as well as for municipalities to support domestic,

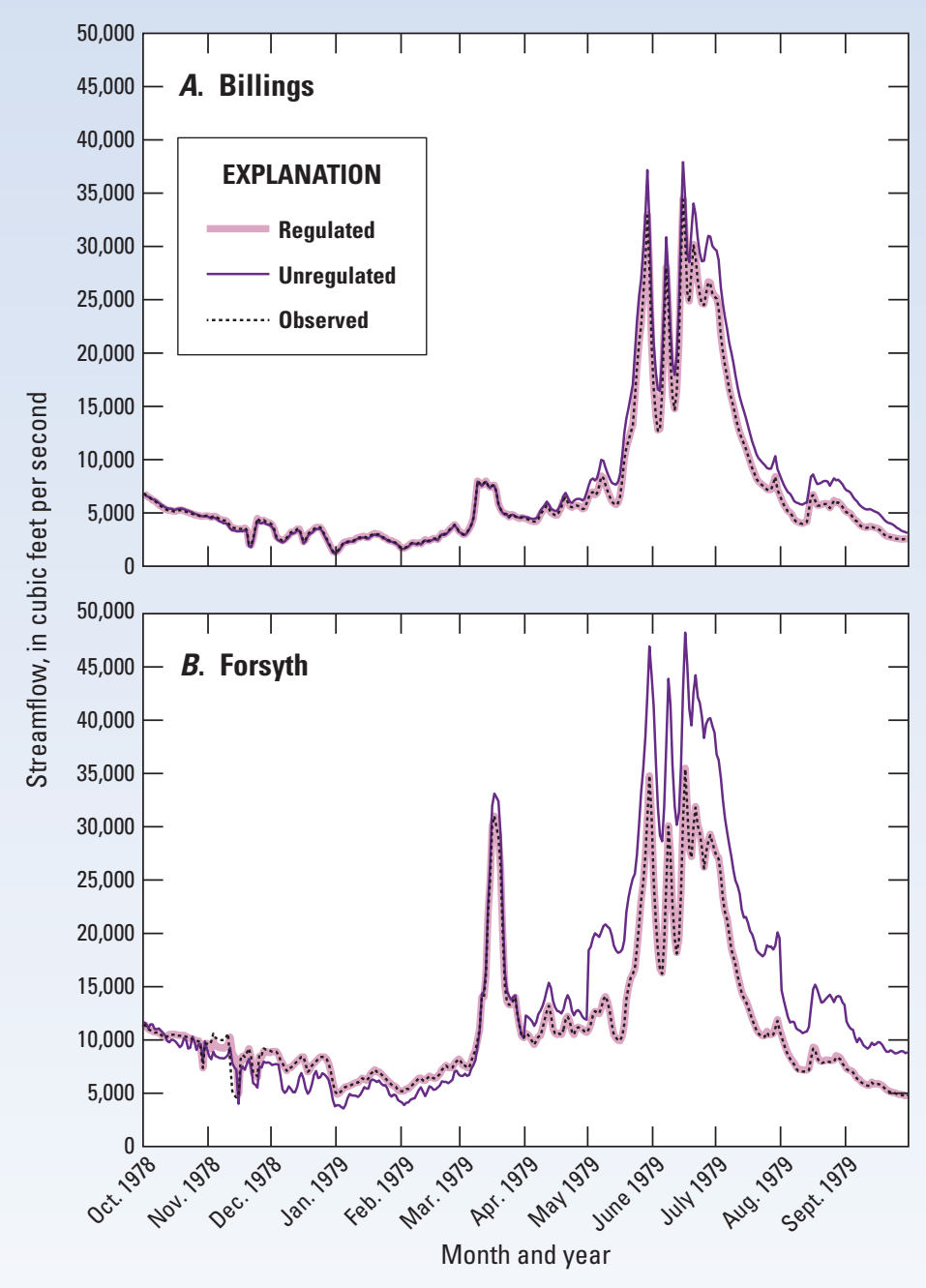

Figure 3. Differences between daily unregulated and regulated streamflow can be seen in hydrographs for October 1978 through September 1979 at the $A$, Yellowstone River at Billings, Montana; and $B$, Yellowstone River at Forsyth, Montana, sites. The regulated hydrograph shows slightly higher streamflow compared to unregulated streamflows at Forsyth in the fall and winter because of water released back into the stream from irrigation return flows and from upstream reservoir releases. Conversely, because of upstream water use, regulated streamflows are lower than unregulated streamflows in the spring and early summer as much as 5,000 cubic feet per second at Yellowstone River at Billings and as much as 16,000 cubic feet per second at Yellowstone River at Forsyth.

Definitions of Technical Terms

\section{observed streamflow}

records Streamflow data measured using a streamgage

unregulated flow Calculated streamflow without water-resource development

regulated flow Calculated streamflow with water-resource development

annual mean flow Mean streamflow for a single year

\section{7-day 50-percent annual non- exceedance probability (ANEP)}

flow The lowest mean streamflow over a consecutive 7-day period with a 50-percent chance of not being equaled or exceeded in a given year. Sometimes called the 7-day 2-year low flow (or 7Q2).

7-day 20-percent ANEP flow The lowest mean streamflow over a consecutive 7-day period with a 20-percent chance of not being equaled or exceeded in a given year. Sometimes called the 7-day 5-year low flow (or 7Q5).

\section{0-day 50-percent ANEP flow}

The lowest mean streamflow over a consecutive 30-day period with a 50-percent chance of not being equaled or exceeded in a given year. Sometimes called the 30-day 2-year low flow (or 30Q2).

\section{0-day 20-percent ANEP flow}

The lowest mean streamflow over a consecutive 30-day period with a 20-percent chance of not being equaled or exceeded in a given year. Sometimes called the 30-day 5-year low flow (or 30Q5).

\section{0-percent annual exceedance probability (AEP) flood Stream-} flow that has a 50-percent chance of being equaled or exceeded in any given year. Sometimes called the 2-year flood.

20-percent AEP flood Streamflow that has a 20-percent chance of being equaled or exceeded in any given year. Sometimes called the 5-year flood.

1-percent AEP flood Streamflow that has a 1-percent chance of being equaled or exceeded in any given year. Sometimes called the 100-year flood. 
commercial, and industrial water use. Low streamflows also affect ecological conditions such as water quality, fish populations, and a host of other biological communities associated with the river.

Two primary variables are used to describe low-flow characteristics. The first variable is the duration of the lowest flow period during any given year. For example, the 7-day low flow is the lowest mean streamflow for any consecutive 7-day period during a given year, and the 30-day low flow is the lowest mean streamflow for any consecutive 30 -day period.

The second variable is the probability, such as 50 percent or 20 percent, of a given low-flow duration occurring in any given year. The combination of these two variables, the duration of the low flow and the probability of occurrence, allows the computation of different statistics to understand how low streamflows might be and is referred to as the low-flow annual non-exceedance probability (ANEP). For example, there is a one in two chance that flows will be lower than an ANEP of 50 percent, whereas for 20-percent low flows, there is a one in five chance that flows will be lower than this value each year. The values for unregulated and regulated 7-day and 30-day low-flow ANEPs for eight streamgages along the Yellowstone River are shown in figure 4.

\section{Unregulated and Regulated Peak Streamflows along the Yellowstone River}

Peak streamflows are important to the health of the Yellowstone River because they improve fish habitats, saturate wetlands, and propagate seedlings.

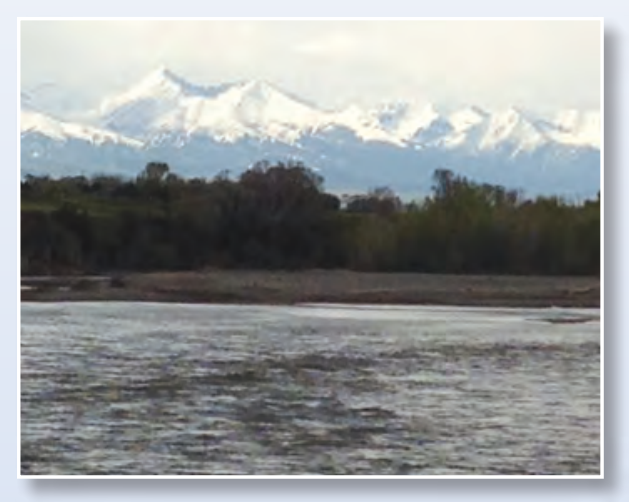

Melting snow from the Crazy Mountains, shown in the background, will reach this section of the Yellowstone River near Big Timber, Montana.
Peak streamflows also can substantially change the stream channel through scouring, transport, and deposition of streambed sediments and can potentially cause damage to communities and river infrastructure. Peak streamflows typically are analyzed and described in terms of how often they might be expected to occur, which relates to a probability or chance of occurrence. At a site, streamflow that has a 50-percent chance of being equaled or exceeded in any given year is referred to as a 50-percent annual exceedance probability (AEP) flood.

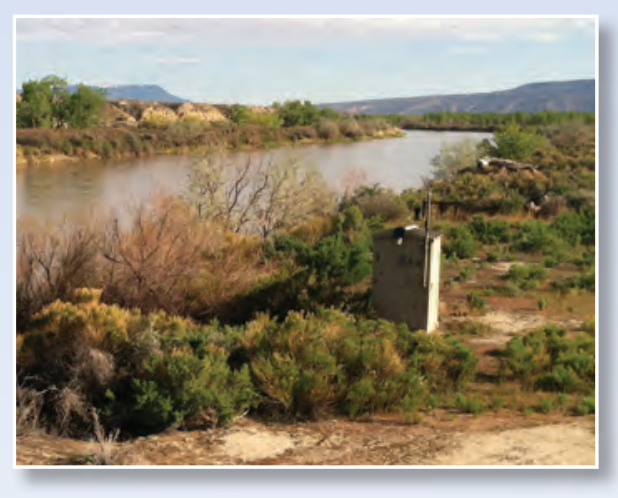

The Bighorn River provides irrigation water to users in the arid Bighorn Basin.

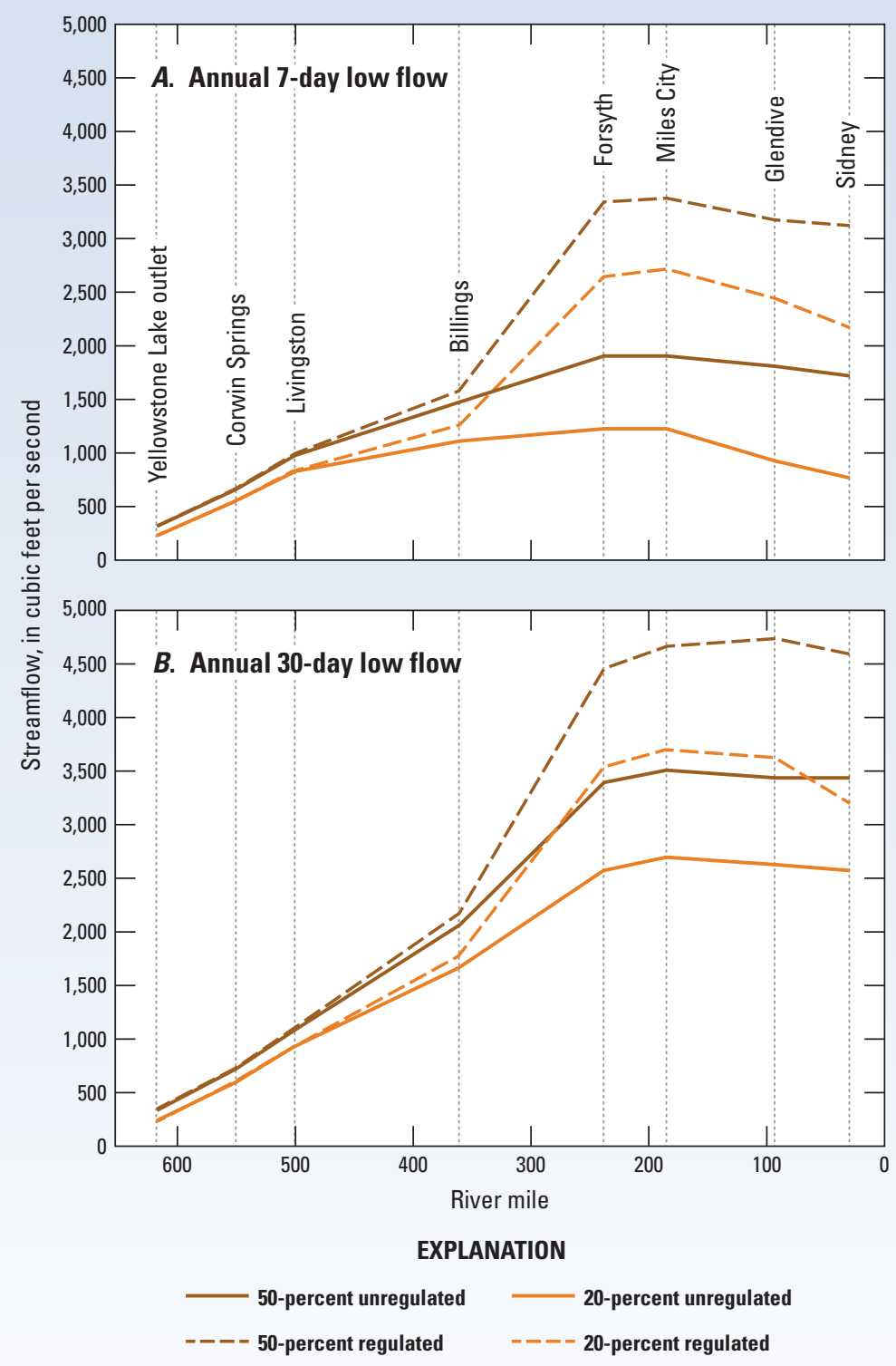

Figure 4. Differences between unregulated and regulated streamflows in the Yellowstone River can be seen in four different calculated annual non-exceedance probabilities. $A$, the 7-day 50-percent and 7-day 20 -percent probability. $B$, the 30 -day 50-percent and 30-day 20-percent probability. These probabilities indicate that low flows for regulated conditions are higher than for unregulated conditions. In particular, the low flows in the Yellowstone River downstream from Billings would be lower for a 7-day period or 30-day period if no regulation occurred in the Yellowstone River Basin. 
Similarly, streamflows with a 20-percent or a 1-percent chance of being equaled or exceeded in any given year are referred to as a 20-percent AEP flood or a 1-percent AEP flood, respectively. Values for unregulated and regulated peak streamflows for the 50-, 20-, and 1-percent AEP floods for eight sites along the Yellowstone River are shown in figure 5.

At the Yellowstone Lake outlet, Corwin Springs, and Livingston sites (figs. 1 and 5), unregulated and regulated streamflows are nearly equal because

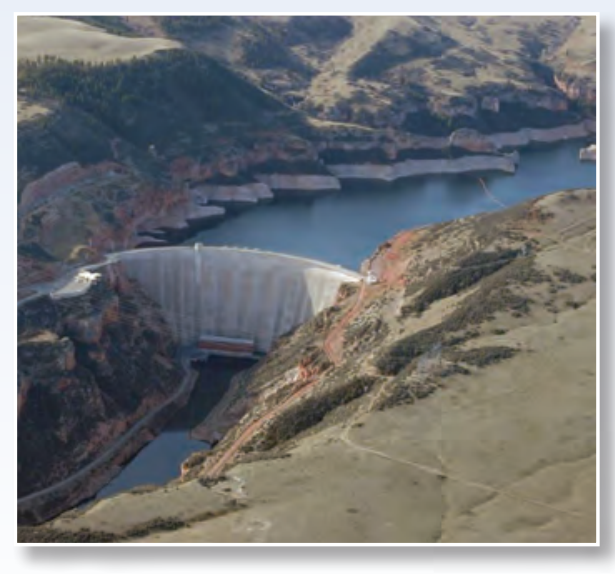

Yellowtail Dam on the Bighorn River, a tributary of the Yellowstone River, creates Bighorn Lake in northern Wyoming. Photograph by National Park Service. little water-resource development occurs in the upstream part of the Yellowstone River Basin. At the Billings site, unregulated peak streamflows are slightly higher than regulated peak streamflows, similar to the 1979 hydrograph in figure 3 . The differences between unregulated and regulated peak streamflows are much larger downstream from Billings, primarily because of the effects of the Bighorn River, a highly regulated stream, which joins the Yellowstone River upstream from Forsyth.

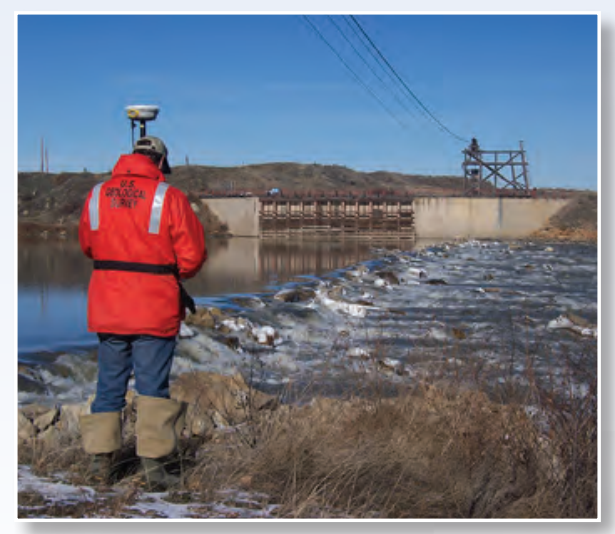

U.S. Geological Survey personnel survey a diversion structure on the Yellowstone River at Intake, Montana. The structure (modified after the photograph was taken in 2006) channels water into a canal to be used for irrigation.

\section{Depletions}

Much of the water in the Bighorn River Basin is used for agriculture, and reservoirs have been constructed to store water. The U.S. Bureau of Reclamation $(1999,2005)$ estimated depletions, changes to natural streamflow, which result from water-resource development during 1928-2002. Average annual depletions for 1928-2002 estimated for areas upstream from each USGS streamgage on the Yellowstone River and for the area upstream from the Bighorn confluence are shown on figure 5. These mean annual depletions mostly represent water that leaves the Yellowstone River Basin by evapotranspiration from reservoirs and from irrigated fields, and by seepage from reservoirs and irrigation canals into the groundwater system. Water-resource development steadily increases from Livingston to Billings, with a larger increase at the Bighorn River confluence. The depletions depicted in figure 5 represent water that annually leaves the Yellowstone River Basin (1) because of irrigation and (2) because of the combination of irrigation, and water stored in the major reservoirs in the Bighorn River Basin (Boysen Reservoir, Buffalo Bill Reservoir, and Bighorn Lake).

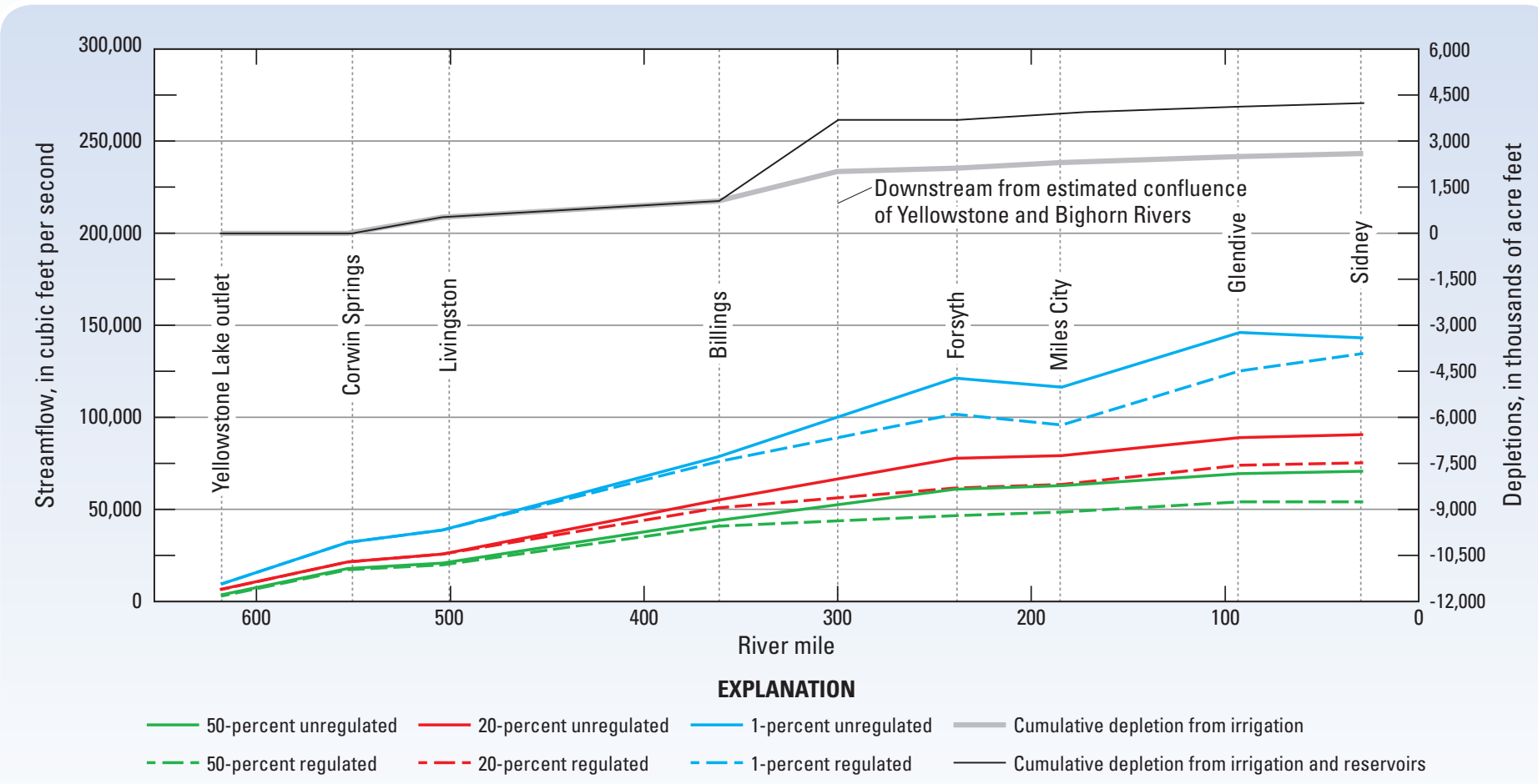

Figure 5. Six different calculated annual exceedance probabilities for eight sites along the Yellowstone River show different peak streamflows based on the probability of occurrence and whether the streamflow was unregulated or regulated. The greatest differences between unregulated and regulated peak streamflows in the Yellowstone River can be seen at the Forsyth, Miles City, and Glendive sites. 
Comparison of the water that annually leaves because of irrigation with water that leaves because of the combination of irrigation and water stored in the reservoirs, indicates that storage in the Bighorn River Basin reservoirs makes up a large part of water that leaves the Yellowstone River Basin.

\section{Using the Information}

Scientists are using the unregulated and regulated streamflow statistics to understand how water-resource development has altered streamflows in the Yellowstone River Basin and how these changes have affected river flood-plain extents, low-flow hydraulics, fish habitat, and water quality. Water managers are in the process of developing protocols and practices that will increase the health of the river while balancing the multiple uses and needs of the river (Johnson, 2014). These studies and data will help managers to understand the Yellowstone River system, allowing them to make informed decisions about the future of the river to balance the multiple uses and needs of the river.

\section{References}

Chase, K.J., 2013, Streamflow statistics for unregulated and regulated conditions for selected locations on the Yellowstone, Tongue, and Powder Rivers, Montana, 1928-2002 (ver. 1.1, June 2014): U.S. Geological Survey Scientific Investigations Report 2013-5173, 183 p. [Also available at http://dx.doi. org/10.3133/sir20135173.]
Chase, K.J., 2014, Streamflow statistics for unregulated and regulated conditions for selected locations on the Upper Yellowstone and Bighorn Rivers, 1928-2002: U.S. Geological Survey Scientific Investigations Report 2014-5115, 117 p. [Also available at http://dx.doi.org/10.3133/sir20145115.]

Johnson, C., 2014, Yellowstone River study heading into home stretch: Billings, Montana, The Billings Gazette, 5 p., accessed December 3, 2014, at http://yellowstonerivercouncil. org/news/wordpress-content/ uploads/2014/10/Yellowstone-Riverstudy-heading-into-home-stretch.pdf.

Olson, S.A., and Norris, M.J., 2005, U.S. Geological Survey Streamgaging...from the National Streamflow Information Program: U.S. Geological Survey Fact Sheet 2005-3131, 4 p. [Also available at http://pubs.usgs.gov/ fs/2005/3131/.]

PBS\&J, 2009, Irrigation in Montana-A Preliminary Inventory of Infrastructure Condition: Missoula, Mont., PBS\&J Report, 91 p., accessed January 12, 2015, at http://dnrc. mt.gov/cardd/ResourceDevelopment/ IrrigationDevelopment/docs/InventoryI rrigationInfrastructureMontana.pdf.

U.S. Army Corps of Engineers, 2011a, Yellowstone River corridor study, Lower Bighorn River hydrology: Omaha, Nebr., U.S. Army Corps of Engineers Engineering Division, Hydrologic Engineering Branch, Hydrology Section, Final Report, 22 p.
U.S. Army Corps of Engineers, 2011b, Yellowstone River corridor study, Upper Yellowstone River hydrology: Omaha, Nebr., U.S. Army Corps of Engineers Engineering Division, Hydrologic Engineering Branch, Hydrology Section, Final Report, 63 p.

U.S. Bureau of Reclamation, 1999, A study to determine the historic and present-level streamflow depletions in the Missouri River Basin above Hermann, Missouri, Appendix F-C of Upper Mississippi River system flow frequency study: Billings, Mont., U.S. Department of the Interior, Bureau of Reclamation, Water Resources Service Group, Great Plains Regional Office, [variously paged].

U.S. Bureau of Reclamation, 2005, A study to determine the historic and present-level streamflow depletions in the Missouri River Basin for the period 1929 to 2002: Billings, Mont., U.S. Department of the Interior, Bureau of Reclamation, Water Resources Service Group, Great Plains Regional Office, [variously paged].

Yellowstone River Conservation District Council, 2014, About YRCDC: accessed June 20, 2014, at http://www. yellowstonerivercouncil.org/about.php.

By Cheryl A. Eddy-Miller and Katherine J. Chase

\section{For more information, contact:}

Katherine Chase

U.S. Geological Survey

3162 Bozeman Avenue

Helena, MT 59601

406-457-5957, kchase@usgs.gov

ISSN 2327-6932 (online)

http://dx.doi.org/10.3133/ss20153004 